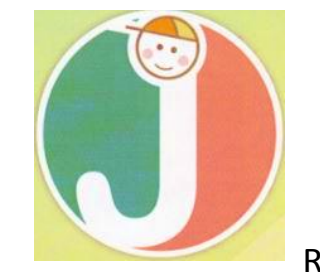

\author{
JEA (JURNAL EDUKASI AUD) \\ PENDIDIKAN ISLAM ANAK USIA DINI \\ UNIVERSITAS ISLAM NEGERI ANTASARI BANJARMASIN \\ DOI: 10.18592/jea.v6i1.3590
}

Received: 29042020 / Accepted: 20052020 / Published online: 01072020

\title{
PENGARUH PENDIDIKAN, PEKERJAAN DAN POLA ASUH ORANG TUA TERHADAP KEMANDIRIAN ANAK
}

\author{
Noor Baiti \\ Universitas Muhammadiyah Banjarmasin \\ E-mail: noorbaiti055@gmail.com
}

\begin{abstract}
This study aims to analyze and describe the influence of parental education levels on parenting, parental occupations on parenting, parental education levels on children's independence, parental work on children's independence, parenting on children's independence, parental education levels through parenting to the child's independence, and the work of parents through parenting towards the child's independence. The sample in this study used a simple random sampling of 212 parents and children. Data processing is performed through the help of IBM SPSS program computer version 24.0. The results of the study: There is a direct effect: (1) The level of parental education on parenting in the Kindergarten Alalak District. (2) Parents' work on parenting in the Kindergarten, Alalak District. (3) The level of parental education towards the independence of children in the Kindergarten, Alalak District. (4) Parents work on the independence of children in Kindergarten, Alalak District. (5) Parenting for the independence of children in Kindergarten, Alalak District. There is no indirect effect (6) The level of parental education on the independence of children through parenting in Kindergarten, Alalak District. (7) Parents' work on children's independence through parenting in the Alalak District.
\end{abstract}

Keywords : Education, Work, Parenting and Independence 


\begin{abstract}
Abstrak
Penelitian ini bertujuan untuk menganalisis dan mendeskripsikan pengaruh tingkat pendidikan orang tua terhadap pola asuh, pekerjaan orang tua terhadap pola asuh, tingkat pendidikan orang tua terhadap kemandirian anak, pekerjaan orang tua terhadap kemandirian anak, pola asuh terhadap kemandirian anak, tingkat pendidikan orangtua melalui pola asuh terhadap kemandirian anak, dan pekerjaan orang tua melalui pola asuh terhadap kemandirian anak. Sampel pada penelitian ini menggunakan simple random sampling sebanyak 212 orang orang tua dan anak. Pengolahan data dilakukan melalui bantuan komputer program IBM SPSS versi 24.0. Hasil penelitian: Ada pengaruh langsung: (1) Tingkat pendidikan orangtua terhadap pola asuh di TK Gugus Kecamatan Alalak (2) Pekerjaan orangtua terhadap pola asuh di TK Kecamatan Alalak (3) Tingkat pendidikan orangtua terhadap kemandirian anak di TK Kecamatan Alalak (4) Pekerjaan orangtua terhadap kemandirian anak di TK Kecamatan Alalak. (5) Pola asuh terhadap kemandiran anak di TK Kecamatan Alalak Tidak ada pengaruh tidak langsung (6) Tingkat pendidikan orangtua terhadap kemandirian anak melalui pola asuh di TK Kecamatan Alalak (7) Pekerjaan orangtua terhadap kemandirian anak melalui pola asuh di TK Kecamatan Alalak
\end{abstract}

Kata Kunci : Pendidikan, Pekerjaan, Pola Asuh,

\title{
Pendahuluan
}

Masa anak-anak merupakan waktu dimana anak-anak mengalami fase keemasan. Masa ini anak perlu dasar pengasuhan yang baik, seperti dalam pribahasa mengatakan belajar dimasa kecil bagai mengukir diatas batu yang berarti ketika kita belajar atau menuntut ilmu dari kecil, maka ilmu itu akan terukir permanen dalam kepala kita karena pemikiran 
dimasa kanak-kanak masih bersih, murni dan belum terlalu banyak beban pikiran. Sehingga pentingnya adanya penanaman nilai-nilai kebaikan dari orang-orang disekitarnya terutama lingkungan dalam keluarga karena bagaimanapun keluarga adalah madrasah pertama anak-anak.

Berbagai pengamatan mengenai kemandirian anak ditemukan hasil bahwa anak-anak di Indonesia termasuk dalam kategori yang anak-anak lambat dalam hal kemandirian, ini semua dikarenakan tidak adanya kesadaran diri orang tua dalam melatih kemandirian itu sendiri (Fadillah, 2016).

Para dasarnya orang tua dan guru PAUD dituntut untuk dapat membentuk kemandirian anak secara selektif dan seoptimal mungkin, maka diperlukan adanya faktor-faktor untuk mendorong kemandiran anak tersebut. Faktor-faktor yang berpengaruh terhadap kemandirian anak usia dini dibagi menjadi dua faktor yaitu internal dan eksternal (Wiyani, 2015).

Faktor internal yaitu yang ada dalam diri anak itu sendiri meliputi emosi dan intelektual. Faktor fisiologis atau emosi ini contohnya anak mampu mengendalikan emosinya bahkan saat dia dalam kondisi yang tidak membuatnya nyaman sekalipun. Faktor psikologis atau intelektual contohnya anak mampu mengatasi masalah yang dihadapinya. Sedangkan Faktor eksternal adalah faktor yang ada di luar dari diri anak itu sendiri. Faktor-faktor tersebut seperti lingkungan, karakteristik, sosial, stimulasi, pola asuh, cinta dan kasih sayang, kualitas informasi anak dan orang tua, pendidikan orang tua dan status pekerjaan ibu (Wiyani, 2015).

Tingkat atau jenjang pendidikan adalah tahap pendidikan yang berkelanjutan yang ditetapkan berdasarkan tingkat perkembangan peserta didik, tingkat kerumitan bahan 
pengajaran dan cara menyajikan bahan pengajaran (Ihsan, 2003). Tingkat atau jenjang pendidikan formal yang dimaksud dalam penelitian ini terbagi menjadi tiga yaitu: (a) Pendidikan dasar seperti SD atau MI dan SMP atau MTs. (b) Pendidikan menengah seperti SMA atau SMK atau MA. (c) Pendidikan tinggi meliputi program diploma. sarjana, magister, d) doktor.

Pekerjaan secara umum didefinisikan sebagai sebuah kegiatan aktif yang dilakukan oleh manusia, dalam arti sempit istilah pekerjaan digunakan untuk suatu tugas atau kerja yang menghasilkan sebuah karya bernilai imbalan dalam bentuk uang bagi seseorang (Husni, 2003). Pekerjaan orang tua dalam penelitian ini berfokus pada status pekerjaan ibu. Status pekerjaan ibu yang dimaksud adalah ibu tidak bekerja yaitu seorang wanita yang telah menikah serta menjalankan pekerjaan rumah keluarga dengan merawat anak-anaknya, memasak, membersihkan rumah dan tidak bekerja di luar rumah atau ibu rumah tangga dan ibu bekerja yaitu Ibu bekerja yaitu ibu yang melakukan suatu kegiatan di luar rumah dengan tujuan untuk mencari nafkah untuk keluarga (Santrock, 2007).

Pola asuh adalah merupakan hubungan antara anak dan orang tua yang bertugas mendidik, membimbing, dan mendisplinkan serta melindungi anak untuk menjadi manusia yang berbudi pekerti yang baik sesuai dengan norma-norma yang ada dalam masyarakat (Hidayani, 2006). Pola asuh yang dimaksud penelitian ini adalah pola asuh otoriter, demokratis, dan permisif.

Kata mandiri sering disandingkan dengan kata kemandirian, dalam Kamus Bahasa Indonesia mandiri diartikan sebagai keadaan yang dapat menjadikan individu berdiri sendiri, tidak tergantung pada orang lain. Mandiri adalah perbuatan atau 
tingkah laku yang tidak mudah bergantung pada seseorang dalam menuntaskan pekerjaananya.

Menurut Diane Trister Dogde dan Brewer kemandirian anak usia dini dapat dilihat dari pembiasaan dan kepandaian anak dalam kemampuan fisik, percaya diri, bertanggung jawab, disiplin, pandai bergaul, mau berbagi, dan mengendalikan emosi (Komala, 2015).

Dari penjelasan di atas mengenai kemandirian anak ditemukan beberapa faktor yang memengaruhi kemandirian itu sendiri seperti tingkat pendidikan orang tua, pekerjaan orang tua yaitu status pekerjaan ibu, dan pola asuh. Faktor-faktor ini menjadikan alasan peneliti untuk mengetahui seberapa banyak pengaruh faktor-faktor tersebut terhadap kemandirian anak di TK Kecamatan Alalak

\section{Metode Penelitian}

Jenis penelitian ini menggunakan pendekatan kuantitatif deskriptif. Penelitian ini dimaksudkan untuk memperoleh gambaran mengenai seberapa besar pengaruh tingkat pendidikan orang tua dan pekerjaan orang tua dengan pola asuh terhadap kemandirian anak. Dimana variabel tingkat pendidikan orang tua $\left(X_{1}\right)$ pekerjaan orang tua $\left(X_{2}\right)$ pola asuh $\left(X_{3}\right)$ dan kemandirian anak $(\gamma)$.

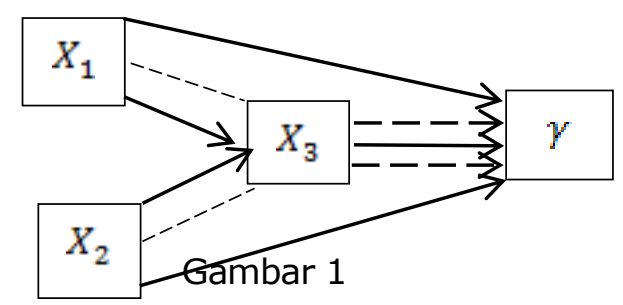

Diagram Pengaruh antar Variabel $\mathrm{X}_{1}, \mathrm{X}_{2}, \mathrm{X}_{\mathrm{a}}$ dan $\mathrm{\gamma}$ 
Populasi dalam penelitian ini seluruh orang tua dan anak di TK Kecamatan Alalak, cara penentuan anggota sampel diambil dengan menggunakan teknik simple random sampling.

Instrumen yang digunakan dalam penelitian ini adalah dengan menggunakan angket, dokumentasi dan observasi. Sedangkan Analisis data yang dipakai untuk menguji hipotesis adalah analisis jalur.

\section{Hasil dan Pembahasan}

Penafsiran hasil analisis jalur dengan uji regresi ganda untuk masing-masing persamaan dengan model struktur I dan model struktur II.

Tabel 1. Ringkasan Hasil Analisis Jalur

Model Struktur I

Tingkat Pendidikan Orang Tua, Pekerjaan Orang Tua terhadap Pola Asuh

\begin{tabular}{lllll}
\hline Variabel & Koefisien Jalur & $\mathrm{T}$ & $\mathrm{p}$ & $\mathrm{R}^{2}$ \\
\hline Tingkat Pendidikan & 0.148 & 2.149 & 0.033 & 0.0 \\
Pekerjaan Orang Tua & 0.141 & 2.055 & 0.041 & 50 \\
\hline
\end{tabular}

Model Struktur II

Tingkat Pendidikan Orang Tua, Pekerjaan Orang Tua, Pola Asuh terhadap Kemandirian Anak

\begin{tabular}{lllll}
\hline Variabel & Koefisien Jalur & $\mathrm{T}$ & $\mathrm{p}$ & $\mathrm{R}^{2}$ \\
\hline Tingkat Pendidikan & 0.229 & 3.474 & 0.001 & 0.1 \\
Pekerjaan Orang Tua & 0.191 & 2.892 & 0.004 & 48 \\
Pola Asuh & 0.144 & 2.196 & 0.029 & 48 \\
\hline
\end{tabular}

Tabel 2. Ringkasan Keputusan Pengujian Hipotesis $\mathrm{H}_{1}, \mathrm{H}_{2}, \mathrm{H}_{3}, \mathrm{H}_{4}$ dan $\mathrm{H}_{5}$

$\mathrm{H}_{1} \quad$ Terdapat pengaruh positif dan signifikansi antara tingkat pendidikan orang tua dan pola asuh $\mathrm{H}_{2} \begin{aligned} & \text { Terdapat pengaruh positif dan signifikansi antara } 0.041 \text { Terima } \\ & \text { pekerjaan orang tua dan pola asuh }\end{aligned}$

$\mathrm{H}_{3}$ Terdapat pengaruh positif dan signifikansi antara tingkat 0.001 Terima pendidikan orang tua dan kemandirian anak

$\mathrm{H}_{4}$ Terdapat pengaruh positif dan signifikansi antara 0.004 Terima 
pekerjaan orang tua dan kemandirian anak

$\mathrm{H}_{5}$ Terdapat pengaruh positif dan signifikansi antara pola asuh orang tua dan kemandirian anak

0.029 Terima

Tabel 1. Ringkasan Keputusan Pengujian Hipotesis $\mathrm{H}_{6}$ dan $\mathrm{H}_{7}$

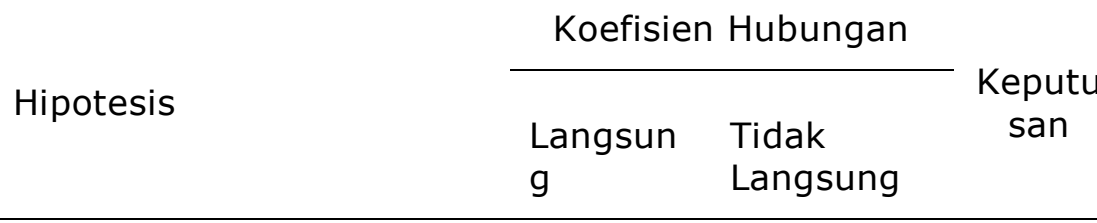

H Pola asuh orang tua merupakan

6 perantara pengaruh tingkat pendidikan orang tua dan kemandirian anak

Pola asuh orang tua merupakan

$\mathrm{H}_{7}$ perantara pengaruh pekerjaan orang tua dan kemandirian anak

0.191

0.020

diterim

a

Analisis deskriptif prequensi pada tabel 1-4 untuk menjawab hipotesis. Pertama tingkat pendidikan orang tua di TK Kecamatan Alalak berdasarkan data yang dilapangan meliputi SD/MI berjumlah 2 orang, SMP/MTs berjumlah 21 orang, SMA/SMK/MA berjumlah 89 orang, D1/D2/D3 berjumlah 34 orang, dan S1 berjumlah 66 orang. Data tersebut menunjukkan bahwa tingkat pendidikan terakhir yang banyak atau lebih dominan dimiliki orang tua berada pada tingkatan SMA/SMK/MA yang berjumlah 89 orang.

Kedua Pekerjaan orang tua yang berfokus pada status pekerjaan ibu bekerja di TK Kecamatan Alalak berdasarkan data yang dilapangan meliputi status ibu tidak bekerja berjumlah 104 orang dan status ibu bekerja 108 orang. Data tersebut menunjukkan bahw status pekerjaan ibu lebih banyak terdapat pada ibu bekerja dengan jumlah 108 orang.

Ketiga Pola asuh orang tua di TK Kecamatan Alalak berdasarkan data yang dilapangan meliputi penerapan pola asuh otoriter berjumlah 44 orang, pola asuh asuh demokratis 
berjumlah 104 orang dan pola asuh permisif berjumlah 64 orang. Jadi dapat disimpulkan bahwa pola asuh yang banyak diterapkan oleh orang tua adalah pola asuh demokratis yang berjumlah 104 orang.

Keempat Kemandirian anak di TK Kecamatan Alalak berdasarkan data yang dilapangan meliputi ketegori belum berkembang berjumlah 1 orang, mulai berkembang berjumlah 8 orang, berkembang sesuai harapan berjumlah 109 orang dan berkembang sangat baik berjumlah 94 orang. Data tersebut menunjukkan bahwa kategori yang lebih banyak ada pada kategori berkembang sangat baik dengan jumlah 109 orang.

\section{Terdapat Pengaruh Tingkat Pendidikan Orang Tua dan Pola Asuh}

Penelitian ini menemukan bahwa ada pengaruh signifikan tingkat pendidikan orang tua terhadap pola asuh. Hal ini dibuktikan dengan nilai koefiisien path sebesar 0,148, yang berarti bahwa terdapat pengaruh antara tingkat pendidikan orang tua terhadap pola asuh di TK Kecamatan Alalak.

Tingkat atau jenjang pendidikan adalah tahap pendidikan yang berkelanjutan yang ditetapkan berdasarkan tingkat perkembangan peserta didik, tingkat kerumitan bahan pengajaran dan cara menyajikan bahan pengajaran (Ihsan, 2003). Penelitian ini menjadikan jalur pendidikan formal sebagai tingkat pendidikan yang akan diteliti. Tingkat pendidikan formal yang dimaksud dalam penelitian ini ada tiga yaitu pendidikan dasar merupakan tingkat pendidikan awal selama sembilan tahun pertama masa sekolah anak-anak yang melandasi tingkat pendidikan menengah. 


\section{Terdapat Pengaruh Pekerjaan Orang Tua dan Pola Asuh}

Temuan penelitian ini menyatakan bahwa ada pengaruh signifikan pekerjaan orang tua terhadap pola asuh. Hal ini dibuktikan dengan nilai koefiisien path sebesar 0,141, yang berarti bahwa terdapat pengaruh antara pekerjaan orang tua terhadap pola asuh di TK Kecamatan Alalak.

Penelitian pada variabel pekerjaan orang tua ini berfokus pada status pekerjaan ibu yaitu ibu yang tidak bekerja dan ibu yang bekerja. Ibu yang bekerja adalah bagian dari kehidupan modern, namun pengaruhnya masih diperdebatkan (Santrock, 2007). Lois Hoffman menjelaskan beberapa kemungkinan pengaruh dari ibu yang bekerja pada perkembangan anak. Bekerja dapat menghasilakan pengaruh positif dan negatif pada pengasuhan. Stres karena pekerjaan bisa meluas dan membahayakan pengasuhan, namun perasaan sejahtera karena bekerja bisa menghasilkan pengasuhan yang lebih positif (Santrock, 2007).

\section{Terdapat Pengaruh Tingkat Pendidikan Orang Tua} dan Kemandirian Anak

Temuan penelitian ini menyatakan bahwa ada pengaruh signifikan tingkat pendidikan orang tua terhadap kemandirian anak. Hal ini dibuktikan dengan nilai koefiisien path sebesar 0,229, yang berarti bahwa terdapat pengaruh antara tingkat pendidikan orang tua terhadap kemandirian anak di TK Kecamatan Alalak.

Eksistensi orang tua sebagai pendidik yang pertama dan utama dalam meletakkan dasar pendidikan terhadap 
anak dan menjadi orang yang bertanggung jawab mendidik anak dengan keimanan dan akhlak, membentuknya dengan kematangan fisik dan psikisnya serta menyerahkannya kepada pemikiran ilmu yang bermanfaat dan bermacam-macam kebudayaannya adalah orang tua (Syafei, 2006).

\section{Terdapat Pengaruh Pekerjaan Orang Tua dan Kemandirian Anak}

Temuan penelitian ini menyatakan bahwa ada pengaruh signifikan pekerjaan orang tua terhadap kemandirian anak. Hal ini dibuktikan dengan nilai koefiisien path sebesar 0,191, yang berarti bahwa terdapat pengaruh antara pekerjaan orang tua terhadap kemandirian anak di TK Kecamatan Alalak.

Pekerjaan orang tua merupakan faktor yang memengaruhi kemandirian, terutama status pekerjaan ibu. (Wiyani, 2015). Kemandirian sendiri memerlukan perhatian orang tua agar terbentuk secara berkala. Dimulai sejak mereka pada usia masih balita sampai mereka remaja. Jika ibu terus menerus sibuk dengan pekerjaannya dikhawatirkan akan sangat berdampak pada pembentukan kemandirian. Anak yang kurang pengawasan dari orang tuanya akan menyebabkan mereka menjadi pribadi yang lebih emosi seperti pemarah, sedangkan anak yang mandiri disebutkan emosinya yang ditunjukkan anak akan terkontrol

\section{Terdapat Pengaruh Antara Pola Asuh Orang Tua dan Kemandirian Anak}

Temuan penelitian ini menyatakan bahwa ada pengaruh signifikan pola asuh terhadap kemandirian anak. 
Hal ini dibuktikan dengan nilai koefiisien path sebesar 0,144 , yang berarti bahwa terdapat pengaruh antara pola asuh terhadap kemandirian anak di TK Kecamatan Alalak.

Keberhasilan keluarga dalam menanamkan nilai-nilai karakter pada anak-anak sangat tergantung pada model dan jenis pola asuh yang diterapkan para orang tua. Pola asuh dapat didefinisikan sebagai pola interaksi antar anak dengan orang tua, yang meliputi kebutuhan fisik seperti makan, minum dan lain-lain serta kebutuhan non fisik seperti perhatian, empati, kasih sayang dan sebagainya (Kurniawan, 2017).

\section{Tidak terdapat Pengaruh Tidak Langsung Antara Tingkat Pendidikan dan Kemandirian Anak Melalui Pola Asuh}

Temuan penelitian ini menyatakan bahwa tidak ada pengaruh signifikan dan tidak ada pengaruh tidak langsung tingkat pendidikan orang tua terhadap kemandirian anak melalui pola asuh. Hal ini dibuktikan dengan nilai koefiisien path sebesar 0,021, yang berarti bahwa tidak terdapat pengaruh antara tingkat pendidikan orang tua terhadap kemandirian anak melalui pola asuh di TK Kecamatan Alalak karena dari hasil hitungan nilai bahwa pengaruh langsung lebih besar daripada pengaruh tidak langsung sehingga tingkat pendidikan orang tua melalui pola asuh terhadap kemandirian anak tidak berpengaruh secara signifikan. 


\section{Tidak terdapat Pengaruh Tidak Langsung Antara Pekerjaan Orang Tua dan Kemandirian Anak Melalui Pola Asuh}

Temuan penelitian ini menyatakan bahwa tidak ada pengaruh signifikan dan tidak ada pengaruh tidak langsung pekerjaan orang tua terhadap kemandirian anak melalui pola asuh. Hal ini dibuktikan dengan nilai koefiisien path sebesar 0,020, yang berarti bahwa tidak terdapat pengaruh antara pekerjaan orang tua terhadap kemandirian anak melalui pola asuh di TK Kecamatan Alalak karena dari hasil hitungan nilai bahwa pengaruh langsung lebih besar daripada pengaruh tidak langsung sehingga pekerjaan orang tua melalui pola asuh terhadap kemandirian anak tidak berpengaruh secara signifikan.

\section{Kesimpulan}

Berdasarkan dari hasil analisis data dan pembahasan sebagaimana diuraikan di atas, dapat disimpulkan sebagai berikut; (1) Ada pengaruh langsung Pekerjaan Orang Tua terhadap Pola Asuh di TK Kecamatan Alalak. (2) Ada pengaruh langsung Tingkat Pendidikan Orang Tua terhadap Kemandirian Anak di TK Kecamatan Alalak. (3) Ada pengaruh langsung Pekerjaan Orang Tua di TK Kecamatan Alalak. (4) Ada pengaruh langsung Pola Asuh terhadap Kemandirian Anak di TK Kecamatan Alalak. (5) Tidak ada pengaruh langsung Tingkat Pendidikan Orang Tua melalui Pola Asuh terhadap Kemandirian Anak di TK Kecamatan Alalak. (6) Tidak ada pengaruh langsung Pekerjaan Orang Tua melalui Pola Asuh terhadap Kemandirian Anak di TK Kecamatan Alalak. 


\section{UCAPAN TERIMA KASIH}

Kami ingin mengucapkan terima kasih yang telah mendukung penelitian ini dalam menulis artikel jurnal ini, para penulis sangat dibantu oleh banyak pihak, terutama kepala sekolah, guru dan orang tua dari TK Kecamatan Alalak, serta Dinas Pendidikan dan Kebudayaan yang telah memberikan kesempatan dan merekomendasikan untuk melakukan penelitian juga bantuan dalam memperoleh data sehingga artikel jurnal ini dapat diselesaikan dengan baik.

\section{Daftar Pustaka}

Fadillah, M. (2016). Pendidikan Karakter Anak Usia Dini. Jogjakarta: Ar-Ruzz Media.

Hidayani, R. (2006). Psikologi Perkembangan Anak. Jakarta: Tanpa Penerbit.

Husni. (2003). Hukum Ketenagakerjaan Indonesia. Jakarta: Raja Grafindo Persada.

Ihsan, F. (2003). Dasar-dasar Kependidikan. Jakarta: Rineka Cipta.

Komala. (2015). Mengenal dan Mengembangkan Kemandirian Anak Usia Dini Melalui Pola Asuh Orang Tua dan Guru. Tunas Siliwangi, Vol 1. No1, 31-45.

Kurniawan, S. (2017). Pendidikan Karakter. Yogyakarta: Arruz Media.

Ranuh, S. (2013). Tumbuh Kembang Anak Edisi 2. Jakarta: Buku Kedokteran EGC.

Santrock, J. (2007). Perkembangan Anak Jilid II Edisi Kesebelas. Jakarta: Erlangga.

Syafei, S. (2006). Bagaimana Anda mendidik Anak. Bogor: Ghalia Indonesia. 
Pengaruh Pendidikan, Pekerjaan Dan Pola Asuh Orang Tua Terhadap Kemandirian Anak

Wiyani, N. A. (2015). Bina Karakter Anak Usia Dini. Yogyakarta: Ar-Ruzz Media. 